\title{
Seroprevalence of Chlamydia abortus infection in yak (Bos grunniens) in Tibet, China
}

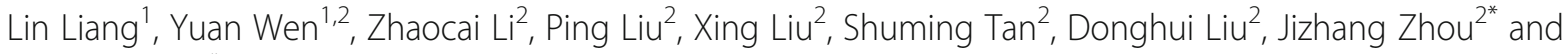 \\ Dewen Tong ${ }^{1 *}$
}

\begin{abstract}
Chlamydia spp. are prevalent zoonotic pathogens that infect a wide variety of host species. Chlamydia abortus (C. abortus) infection in yaks has been reported in Gansu and Qinghai province, China. However, no data about C. abortus infection are available in yaks in Tibet, China. A total of 938 serum samples was collected from yaks in Tibet, China and specific antibodies against $C$. abortus were detected by the enzyme-linked immunosorbent assay (ELISA). The results showed that the overall seroprevalence of $C$. abortus in yaks was 104/938 (11.1\%, $95 \%$ confidence interval [CI] 9.1-13.1). The prevalence in female and male yaks was 59/556 (10.6\%, $95 \% \mathrm{Cl} 8.0-13.2)$ and 45/382 (11.8\%, $95 \%$ Cl 8.5-15.0), respectively with no significant difference $(p>0.05)$. The seroprevalence of antibodies to C. abortus in yaks ranged from 8.0 to $18.2 \%$ among the six different areas, and the difference was also without statistical significance $(p>0.05)$. The prevalence among different age groups ranged from 7.0 to $15.9 \%$, with a higher prevalence among 1 to 2 years age category. The results demonstrate the presence of C. abortus infection in yaks in Tibet and may pose a risk for the general yak populations in addition to its potential impact on public health and the local Tibetan economy. To our knowledge, this is the first seroprevalence survey of $C$. abortus in yaks in Tibet, China.
\end{abstract}

Keywords: Chlamydia abortus, Seroprevalence, Yak, Tibet

\section{Introduction}

Chlamydia spp. are obligate intracellular bacteria with a unique biphasic developmental cycle, which can infect a wide range of animals and humans [1]. Eleven species of the family Chlamydiaceae have been identified along with six newly characterized candidate species [2-6]. Among them, infections in cattle with Chlamydia $(C)$. abortus, $C$. pecorum, C. psittaci, C. suis, C. gallinacea and C. pneumoniae have been reported in many countries around the world, such as Australia, Ireland, Zimbabwe, Poland and

\footnotetext{
* Correspondence: zhoujizhang@caas.cn; dwtong@nwsuaf.edu.cn ${ }^{2}$ State Key Laboratory of Veterinary Etiological Biology, Lanzhou Veterinary Research Institute, Chinese Academy of Agricultural Sciences, 730046 Lanzhou, China

${ }^{1}$ College of Veterinary Medicine, Northwest A\&F University, 712100 Yangling, China
}

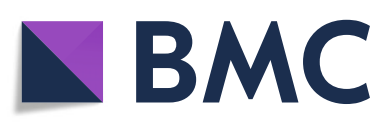

(c) The Author(s). 2021 Open Access This article is licensed under a Creative Commons Attribution 4.0 International License, which permits use, sharing, adaptation, distribution and reproduction in any medium or format, as long as you give appropriate credit to the original author(s) and the source, provide a link to the Creative Commons licence, and indicate if changes were made. The images or other third party material in this article are included in the article's Creative Commons licence, unless indicated otherwise in a credit line to the material. If material is not included in the article's Creative Commons licence and your intended use is not permitted by statutory regulation or exceeds the permitted use, you will need to obtain permission directly from the copyright holder. To view a copy of this licence, visit http://creativecommons.org/licenses/by/4.0/ The Creative Commons Public Domain Dedication waiver (http://creativecommons.org/publicdomain/zero/1.0/) applies to the data made available in this article, unless otherwise stated in a credit line to the data.
China [7-12]. C. abortus is an important pathogen in cattle, capable of causing, premature birth, stillborn or weak offspring $[8,13]$. It can also cause zoonotic infection, especially in pregnant women, where infection can lead to pelvic inflammatory disease, placental dysfunction and lateterm fetal death [14].

There are approximately 14 million yaks in the Qinghai-Tibetan Plateau area of China, representing about $90 \%$ of the yak population in the world. The yak is very important to native Tibetans, because of its high-quality fur, wool, meat and milk. C. abortus is an important pathogen of yak, capable of causing abortion in pregnant yak [15]. While data on the seroprevalence of C. abortus in yaks is available for Qinghai and Gansu provinces of China $[16,17]$, there is no information on the prevalence of C. abortus is in yaks in Tibet, China to the best of our 
knowledge. In this study, we investigated the seroprevalence of $C$. abortus and risk factors including location, gender and age of yaks in Tibet.

\section{Materials and methods}

The study was carried out in Nierong county and Seni district of Naqu city, north Tibet in June 2019. Naqu City has an average altitude of $4,500 \mathrm{~m}$. It is the highest place in China and called "the roof of the world".

A total of 938 blood samples were collected randomly from apparently healthy yaks. Four hundred were collected in Nierong County area (Xiaqu, Seqing), including 247 females and 153 males while 538 samples were collected in the Seni district (Luoma, Namaqie, Dasha, Mufa), including 309 females and 229 males. The blood samples were placed at room temperature for $4 \mathrm{~h}$ and quickly transferred to the laboratory, and centrifuged at $3000 \mathrm{~g}$ for $10 \mathrm{~min}$ to obtain sera that were stored at -80 ${ }^{\circ} \mathrm{C}$ until use.

Anti-C. abortus IgG antibodies were detected with ELISA kits according to the manufacturer's instructions (ID Screen ${ }^{\circledR}$ Chlamydophila abortus Indirect Multispecies, IDVET Innovative Diagnostics, Montpellier, France). The optical density (OD) was measured at 450 $\mathrm{nm}$ by an ELISA microplate reader Multiskan $^{\mathrm{Tm}} \mathrm{FC}$, Thermo Fisher Scientific ${ }^{\mathrm{Tm}}$, USA). Signal to noise ratio was calculated according to the following formula:

$\mathrm{S} / \mathrm{P}(\%)=100 \times(\mathrm{OD}$ sample / OD positive control $)$.

Where S: tested sample, P: positive control.

Sera samples with $\mathrm{S} / \mathrm{P}$ ratios higher than $60 \%$ were considered positive.

The differences in infection rate based on location, genders and age groups of yaks were analyzed by Chisquare test in SPSS (Statistical Analysis System, Version $22.0)$. Values of $p<0.05$ were considered statistically significant.

\section{Results and discussion}

Of the 938 serum samples, 104/938 (11.1\%, $95 \%$ CI 9.1-13.1) were positive for C. abortus including 59/556 (10.6\%, $95 \%$ CI $8.0-13.2)$ female yaks and $45 / 382$ (11.8\%, 95\% CI 8.5-15.0) male yaks (Table 1), the
Table 1 Prevalence of Chlamydia abortus infection in yaks by gender in Tibet, China

\begin{tabular}{lccll}
\hline Gender & Number Tested & $\begin{array}{c}\text { Number } \\
\text { Positive }\end{array}$ & Prevalence \% $(\mathbf{9 5} \% \mathrm{Cl})$ & $\boldsymbol{p}$ \\
\hline Female & 556 & 59 & $10.6(8.0-13.2)$ & 0.575 \\
Male & 382 & 45 & $11.8(8.5-15.0)$ & \\
Total & 938 & 104 & $11.1(9.1-13.1)$ & \\
\hline
\end{tabular}

difference, however, was not statistically significant $(p>$ $0.05)$. Antibodies against $C$. abortus in yak varied from 8.0 to $18.2 \%$ among the different regions but the difference was not statistically significant $(p>0.05)$ (Table 2$)$. The seroprevalence among the different age groups ranged from 7.0 to $15.9 \%$ (Table 3) and was higher in the 1 to 2 years category, but was not significantly different $(p>0.05)$.

According to our results, the seroprevalence of yak $C$. abortus in Tibet was lower than that in Qinghai $(17.66 \%)$ and Gansu provinces (16.22\%) of China [16, $17]$, and in India (35\%) [18], but higher than the prevalence reported in Ireland and Poland $[8,11]$. This difference may be related to the sample collection, feeding method, species and age of animals, as well as different detection methods, such as indirect hemagglutination assay (IHA) and ELISA which can cause a significant difference in seroprevalence rates because of differences in test sensitivity.

There was no significant difference in the prevalence in female and male yaks $(p>0.05)$, which was consistent with the results of white yaks in Gansu [17] and yaks in Qinghai Province [16]. The same results have been observed in studies on other animal species such as the Tibetan pigs in Tibet, China [19]. These findings suggested that gender might not be a key factor in C. abortus infection in Tibet animal populations.

Tibetan yaks basically live at an altitude of 5,000 m above sea level. High altitude is the most important ecological challenge for yaks. In this study, antibodies against C. abortus in yak varied from 8.0 to $18.2 \%$ between regions. The highest seroprevalence for C. abortus was in Xiaqu township. The more intensive husbandry

Table 2 Prevalence of Chlamydia abortus infection in yaks by areas in Tibet, China

\begin{tabular}{llccc}
\hline & Area & Number Tested & $\begin{array}{c}\text { Number } \\
\text { Positive }\end{array}$ & Prevalence \% (95\% Cl) \\
\hline Seni & Luoma & 116 & 10 & $8.6(3.4-13.8)$ \\
& Namaqie & 161 & 19 & $11.8(6.8-16.8)$ \\
& Dasha & 161 & 22 & $13.7(8.3-19.0)$ \\
& Mufa & 100 & 11 & $11.0(4.8-17.2)$ \\
& Xiaqu & 99 & 18 & $18.2(10.5-25.9)$ \\
& Seqing & 301 & 24 & $8.0(4.9-11.1)$ \\
& Total & 938 & 104 & $11.1(9.1-13.1)$ \\
\hline
\end{tabular}


Table 3 Prevalence of Chlamydia abortus infection in yaks by age in Tibet, China

\begin{tabular}{lccc}
\hline Age group & Number Tested & Number Positive & Prevalence \% $(\mathbf{9 5} \% \mathbf{C l})$ \\
\hline $1<$ age $\leq 2$ & 107 & 17 & $15.9(8.8-22.9)$ \\
$2<$ age $\leq 3$ & 129 & 18 & $14.0(7.9-20.0)$ \\
$3<$ age $\leq 4$ & 174 & 18 & $10.3(5.8-14.9)$ \\
$4<$ age $\leq 5$ & 143 & 17 & $11.9(6.5-17.3)$ \\
$5<$ age $\leq 6$ year & 181 & 16 & $8.8(4.7-13.0)$ \\
$6<$ age $\leq 7$ & 133 & 13 & $9.8(4.7-14.9)$ \\
age $>7$ & 71 & 5 & $7.0(0.9-13.1)$ \\
Total & 938 & 104 & $11.1(9.1-13.1)$ \\
\hline
\end{tabular}

found in townships such as Xiaqu suggests that close contact at feeding may be a risk factor for the increased prevalence of $C$. abortus.

Among the different age groups, a higher prevalence $(15.9 \%)$ was detected in the 1 to 2 year age category but was not significant $(p>0.05)$, This pattern of age-related seroprevalence has also been observed in previous surveys of yaks elsewhere in China $[16,17]$ and was also not different from reports in cattle in Guangzhou, China [20]. High seroprevalence among members of the 1-2 years age category could be due to lower resistance or immunity, chronic infection, or sustained infection in yaks of this age.

Tibet is one of four major pastoral areas and an important grassland animal husbandry production base in China. There are about 4 million yaks in Tibet which makes it an economically important livestock species. Yaks abortion caused by C. abortus infection in Qinghai province has been reported previously [15]. However, the prevalence of $C$. abortus in yak population in the vast Tibet area is not known. The current study showed an overall serological positive ratio of $11.1 \%$ by a $C$. abortus antibody-specific ELISA kits. According to local herdsmen, yak flocks suffered abortions in Tibet in recent years. We believe that some of the yak abortion cases might be the outcome of $C$. abortus infection in the yak population, although $C$. abortus-related abortion has not been investigated. C. abortus is a known zoonotic bacterial pathogen. Several reports have demonstrated that humans can acquire infection through contact with infected animals or aborted feteus and placenta, resulting in severe health problems including atypical pneumonia in men and abortion or pelvic inflammatory diseases in women $[21,22]$. It might be a potential risk for public health.

In conclusion, the results showed a C. abortus seroprevalence of $11.1 \%$ in yaks in Tibet, China. To our knowledge, the present report is the first to document the seroprevalence of $C$. abortus infection in yaks in Tibet, China. Further work is required to establish the significance of C. abortus infection in Tibetan yaks.

\section{Abbreviations}

$\mathrm{Cl}$ : Confidence interval; IHA: Indirect hemagglutination assay; ELISA: Enzymelinked immunosorbent assay

\section{Acknowledgements}

The authors wish to thank the staff of the Institute of Animal Husbandry and Veterinary Medicine, Tibet Academy of Agriculture and Animal Husbandry Sciences, for their great help during the serology work.

\section{Authors' contributions}

Lin Liang and Yuan Wen carried out the methodology and drafted the manuscript. Zhao-cai Li, Ping Liu, Xing Liu provided the samples and data collection. Shu-ming Tan and Dong-hui Liu conducted the statistical analyses. Ji-zhang Zhou and De-wen Tong revised the manuscript. All authors have read and approved the final version of this manuscript.

\section{Funding}

This study was supported by grants from the Application and Demonstration of Yak Important Epidemic Prevention and Control Technology

(2018YFD0502305).

Availability of data and materials

Please contact the authors for data requests.

\section{Declarations}

Ethics approval and consent to participate

The animal study was reviewed and approved by the Animal Ethics Procedures and Guidelines of the People's Republic of China and Animal Ethics Committee of Lanzhou Veterinary Research Institute, Chinese Academy of Agricultural Sciences (No. LVRIAEC2012-007).

Consent for publication

Not applicable.

\section{Competing interest}

The authors declare that they have no competing interests.

Received: 4 May 2021 Accepted: 22 June 2021

Published online: 30 June 2021

\section{References}

1. Bachmann NL, Polkinghorne A, Timms P. Chlamydia genomics: providing novel insights into chlamydial biology. Trends Microbiol. 2014;22:464-72.

2. Laroucau K, Vorimore F, Aaziz R, Solmonson L, Hsia RC, Bavoil PM. Fach P, Holzer M, Wuenschmann A, Sachse K. Chlamydia buteonis, a new Chlamydia species isolated from a red-shouldered hawk. Syst Appl Microbiol. 2019;42:125997.

3. Staub E, Marti $H$, Biondi R, Levi A, Donati M, Leonard CA, Ley SD, Pillonel T, Greub G, Seth-Smith HMB, Borel N. Novel Chlamydia species isolated from snakes are temperature-sensitive and exhibit decreased susceptibility to azithromycin. Sci Rep. 2018;8:5660. 
4. Taylor-Brown A, Spang L, Borel N, Polkinghorne A. Culture-independent metagenomics supports discovery of uncultivable bacteria within the genus Chlamydia. Sci Rep. 2017;7:10661.

5. Taylor-Brown A, Bachmann NL, Borel N, Polkinghorne A. Cultureindependent genomic characterisation of Candidatus Chlamydia sanzinia, a novel uncultivated bacterium infecting snakes. BMC Genomics. 2016;17:710.

6. Vorimore F, Hsia RC, Huot-Creasy H, Bastian S, Deruyter L, Passet A, Sachse K, Bavoil P, Myers G, Laroucau K. Isolation of a New Chlamydia species from the Feral Sacred Ibis (Threskiornis aethiopicus): Chlamydia ibidis. PLoS One. 2013;8.

7. Li J, Guo W, Kaltenboeck B, Sachse K, Yang Y, Lu G, Zhang J, Luan L, You J, Huang K. Qiu H, Wang Y, Li M, Yang Z, Wang C. Chlamydia pecorum is the endemic intestinal species in cattle while C. gallinacea, C. psittaci and C. pneumoniae associate with sporadic systemic infection. Vet Microbiol. 2016; 193: 93-99.

8. Wilson K, Sammin D, Harmeyer S, Nath M, Livingstone M, Longbottom D. Seroprevalence of chlamydial infection in cattle in Ireland. Vet J. 2012;193: 583-5.

9. Anstey SI, Quigley BL, Polkinghorne A, Jelocnik M. Chlamydial infection and on-farm risk factors in dairy cattle herds in South East Queensland. Aust Vet J. 2019;97:505-8.

10. Ndengu M, Matope G, Tivapasi M, Scacchia M, Bonfini B, Pfukenyi DM, Garine-Wichatitsky M. Sero-prevalence of chlamydiosis in cattle and selected wildlife species at a wildlife/livestock interface area of Zimbabwe. Trop Anim Health Prod. 2018;50:1107-17.

11. Szymanska-Czerwinska M, Niemczuk K, Galinska EM. Serological and nested PCR survey to determine the occurrence of Chlamydia infections in the Polish cattle population. Ann Agric Environ Med. 2013;20:682-6.

12. Van Loo H, Pardon B, De Schutter P, De Bleecker K, Vanrompay D, Deprez P, Maris J. Detection of Chlamydia psittaci in Belgian cattle with signs of respiratory disease and milk drop syndrome. Vet Rec. 2014;175:562.

13. Walker E, Lee EJ, Timms P, Polkinghorne A. Chlamydia pecorum infections in sheep and cattle: A common and under-recognised infectious disease with significant impact on animal health. Vet J. 2015;206:252-60.

14. Pichon N, Guindre L, Laroucau K, Cantaloube M, Nallatamby A, Parreau S. Chlamydia abortus in Pregnant Woman with Acute Respiratory Distress Syndrome. Emerg Infect Dis. 2020;26:628-9.

15. Li Z, Cai J, Cao X, Lou Z, Chao Y, Kan W, Zhou J. Whole-Genome Sequence of Chlamydia abortus Strain GN6 Isolated from Aborted Yak Fetus. Genome Announc. 2017;5:e00893-17.

16. Chen Q, Gong X, Zheng F, Cao X, Li Z, Zhou J. Seroprevalence of Chlamydophila abortus infection in yaks (Bos grunniens) in Qinghai, China. Trop Anim Health Prod. 2014;46:503-7.

17. Qin SY, Huang SY, Yin MY, Tan QD, Liu GX, Zhou DH, Zhu XQ, Zhou JZ, Qian AD. Seroprevalence and risk factors of Chlamydia abortus infection in free-ranging white yaks in China. BMC Vet Res. 2015;11:8.

18. Bandyopadhyay S, Sasmal D, Biswas TK, Samanta I, Ghosh MK. Serological evidence of antibodies against Chlamydophila abortus in free-ranging yak (Poephagus grunniens) in Arunachal Pradesh, India. Rev sci tech Off int Epiz. 2009:28:1051-5.

19. Zhang NZ, Zhou DH, Shi XC, Nisbet AJ, Huang SY, Ciren D, Wu SM, Zhu XQ. First report of Chlamydiaceae seroprevalence in Tibetan pigs in Tibet, China. Vector Borne Zoonotic Dis. 2013;13:196-9.

20. Zhou DH, Zhao FR, Xia HY, Xu MJ, Huang SY, Song HQ, Zhu XQ. Seroprevalence of chlamydial infection in dairy cattle in Guangzhou, southern China. Ir Vet J. 2013;66(1):2.

21. Walder G, Hotzel H, Brezinka C, Gritsch W, Tauber R, Würzner R, Ploner F. An unusual cause of sepsis during pregnancy: recognizing infection with Chlamydophila abortus. Obstetrics \& Gynecology. 2005;106:1215-7.

22. Ortega N, Caro MR, Gallego MC, Murcia-Belmonte A, Alvarez D, Del Rio L, Cuello F, Buendia AJ, Salinas J. Isolation of Chlamydia abortus from a laboratory worker diagnosed with atypical pneumonia. Ir Vet J. 2015;69:8.

\section{Publisher's Note}

Springer Nature remains neutral with regard to jurisdictional claims in published maps and institutional affiliations.

\section{Ready to submit your research? Choose BMC and benefit from:}

- fast, convenient online submission

- thorough peer review by experienced researchers in your field

- rapid publication on acceptance

- support for research data, including large and complex data types

- gold Open Access which fosters wider collaboration and increased citations

- maximum visibility for your research: over $100 \mathrm{M}$ website views per year

At BMC, research is always in progress.

Learn more biomedcentral.com/submissions 